\title{
Approaches for regulating water in South Africa for the presence of pesticides
}

\author{
L London $^{1}$, MA Dalvie ${ }^{1 *}$, A Nowicki $^{1}$ and E Cairncross ${ }^{2}$ \\ ${ }^{1}$ Occupational and Environmental Health Research Unit, Department of Public Health, University of Cape Town, Anzio Rd, \\ Observatory, Cape Town, South Africa \\ ${ }^{2}$ Department of Chemical Engineering, Peninsula Technikon, Bellville, Cape Town, South Africa
}

\begin{abstract}
The public health significance of pesticide pollution of water sources in South Africa has received little attention from policy-makers and regulators, unlike microbiological quality of potable water. This anomaly is reflected in the current legislation in South Africa which is marked by inadequate regulatory standards for pesticides in water. Due to high costs, technical constraints and shortage of laboratory skills for pesticide analyses in South Africa, the poor regulatory framework has no monitoring data on which to base policy. In contrast, international experience in setting standards for maximum permissible levels of pesticides in water is extensive. The different approaches used by the World Health Organisation, the United States Environmental Protection Agency and the European Union are outlined, as well as the assumptions underlying these different approaches. Drawing on these models, recommendations are made as to how to integrate concerns for pesticide safety in environmental regulation and risk assessment in South Africa. Such measures would ensure consistency with recent developments in environmental management in South Africa that give primacy to a number of key environmental policy principles. A public health perspective should ensure that growing international concerns for longterm adverse health and environmental impacts arising from the presence of pesticides in water are adequately addressed in regulatory controls in South Africa.
\end{abstract}

Keywords: Water regulation, standards, pesticides, health

\section{Introduction}

Long-term low-dose exposures to pesticides are increasingly thought to cause chronic health problems, including reproductive, immunological, respiratory, neurological and carcinogenic impacts (Maroni and Fait, 1993; Schettler et al., 1996; Gray and Ostby, 1998; Dalvie et al., 1999; Porter et al., 1999; Kirkhorn and Schenker, 2002; Colosio et al., 2003). Although much of the scientific evidence for these associations stems from epidemiological studies in the workplace, environmental routes of exposure, including ingestion of pesticides in water, are thought to be of greater public health significance because of the very large numbers of people potentially exposed, the difficulties in controlling chemically contaminated environments and the fact that small changes in contaminant levels may have significant adverse population outcomes (Barnes and Kalita, 2001; McKay and Moeller, 2001).

The public health significance of pesticide pollution of water sources in South Africa has received relatively little attention from policy-makers and regulators, unlike microbiological quality of potable water, which remains a high priority of legislative measures. This anomaly is reflected in the current drinking water guidelines in South Africa (Department of Water Affairs and Forestry, 1996a), which have detailed standards for inorganics and coliform content (Table 1) but few standards for organic contaminants, and only one standard for a pesticide, atrazine. Given that South Africa is the main market for pesticides in sub-Saharan Africa (Dinham, 1993), this is an important gap.

\footnotetext{
* To whom all correspondence should be addressed.

壆+2721 406-6610; fax:+2721 406-6163;

e-mail: aqiel@cormack.uct.ac.za

Received 19 April 2004; accepted in revised form 21 September 2004.
}

Monitoring for pesticides in water is made difficult in South Africa by a range of factors. These include the high costs of analyses, and of analytical equipment required such as a gas chromatograph, high-pressure liquid chromatograph and mass spectrometer. There is also a shortage of laboratory skills and institutional capacity available in South Africa for pesticide analyses (Rother and London, 1998) and an absence of practical, feasible and cost-effective field monitoring protocols (Dalvie et al., 2002).

The absence of a regulatory framework and water standards for, and monitoring data on pesticides, means that South Africa lacks the capacity to address a potentially serious public health matter. It is usually the poorest and most marginalised groups in society who bear the brunt of environmental pollution from pesticides (London and Rother, 1998).

\section{International water standards}

In contrast, international experience in setting standards for maximum permissible levels of pesticides in water is extensive due to concerns for adverse health and environmental impacts, even at low levels and particularly for organic pesticides of high persistence. Standards for human health (Table 2) are generally much less stringent than standards for aquatic ecosystems (Table 3).

There are two approaches in setting drinking water standards internationally. Agencies such as the World Health Organisation (WHO) and the US Environmental Protection Agency (EPA) adopt a health-risk based approach whereby safe levels for humans are inferred using various extrapolations, assumptions and safety factors from toxicological data obtained on laboratory animals. More recently, the EPA has even moved to consider using data from human experiments to set pesticide tolerances (Anonymous, 2003), an action somewhat controversial in the scientific community 


\begin{tabular}{|c|c|}
\hline \multicolumn{2}{|c|}{$\begin{array}{l}\text { TABLE1 } \\
\text { Current South African drinking water guidelines }\end{array}$} \\
\hline Substance & $\begin{array}{l}\text { Target water quality } \\
\text { range: Domestic use }\end{array}$ \\
\hline Algae & 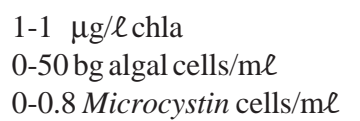 \\
\hline Aluminium & $0-0.15 \mathrm{mg} / \ell$ \\
\hline Ammonia & $0-1.0 \mathrm{mg} \mathrm{NH} / \mathrm{l}$ \\
\hline Arsenic & $0-0.01 \mathrm{mg} / \ell^{3}$ \\
\hline Asbestos & $0-1 \times 10$ fibres $/ \ell$ \\
\hline Atrazine & $0-0.002 \mathrm{mg} / \ell$ \\
\hline Cadmium & $0-5 \mu \mathrm{g} / \ell$ \\
\hline Calcium & $0-32 \mathrm{mg} \mathrm{Ca} / \ell$ \\
\hline Chloride & $0-100 \mathrm{mg} / \ell$ \\
\hline Chromium (VI) & $0-0.05 \mathrm{mg} / \ell$ \\
\hline Coliforms & $0-5(C)$ counts $/ 100 \mathrm{~m} \ell$ \\
\hline Coliphages & $0-1$ counts $/ 100 \mathrm{~m} \ell$ \\
\hline Copper & $0-1 \mathrm{mg} / \ell$ \\
\hline Dissolved organic carbon & $0-5 \mathrm{mg} \mathrm{C} / \ell$ \\
\hline Enteric viruses & $<1$ TCID50/10l \\
\hline Fluoride & $0-1 \mathrm{mg} / \ell$ \\
\hline Iron & $0-0.1 \mathrm{mg} / \mathrm{\ell}$ \\
\hline Lead & $0-0.01 \mathrm{mg} / \ell$ \\
\hline Magnesium & $0-30 \mathrm{mg} / \ell$ \\
\hline Manganese & $0-0.05 \mathrm{mg} / \ell$ \\
\hline Mercury & $0-0.001 \mu \mathrm{g} / \ell$ \\
\hline Nitrate/Nitrite & $0-6$ (a \& b) mg/l \\
\hline Odour & $1 \mathrm{t}$ \\
\hline Organic carbon & $0-5 \mathrm{mg} / \ell$ \\
\hline $\mathrm{PH}$ & 6-9 pH units \\
\hline Phenol & $0-1 \mu \mathrm{g} / \ell$ \\
\hline Potassium & $0-50 \mathrm{mg} / \ell$ \\
\hline Protozoan parasites & $<1$ cysts or oocysts/10l \\
\hline Radionuclides & 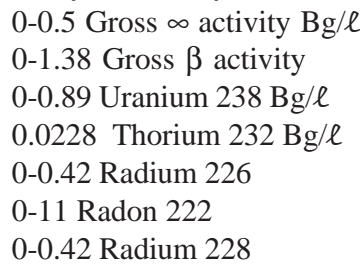 \\
\hline Selenium & $0-0.02 \mathrm{mg} / \ell$ \\
\hline Sodium & $0-100 \mathrm{mg} / \ell$ \\
\hline Sulphate & $0-200 \mathrm{mg} / \mathrm{l}$ \\
\hline Total dissolved solids & $0-450 \mathrm{mg} / \mathrm{l}$ \\
\hline Trihalomethanes & $0-100 \mu \mathrm{g} / \ell$ \\
\hline Turbidity & 0-1 NTU \\
\hline Vanadium & $0-0.1 \mathrm{mg} / \ell$ \\
\hline Zinc & $0-3 \mathrm{mg} / \ell$ \\
\hline
\end{tabular}

(Kamenetsky, 2003). In contrast, the European Economic Community has taken a more stringent approach by setting permissible levels of pesticides at the lowest limit of analytical capability as a means to drive down exposures to pesticides (EEC, 1980; Premazzi and Ziglio, 1995).

The EPA approach to non-carcinogens is to establish minimum contaminant levels (MCLs) and minimum contaminant level goals (MCLGs) which are based on an acceptable daily intake (ADI), the ingested amount of pesticides allowed for humans extrapolated from toxicological data. MCLGs differ from MCLs by taking account of the practical feasibility of implementing a standard but are set as close as possible to MCLs. For carcinogens, the EPA models the amount of pesticide intake associated with an "acceptable" risk (a lifetime increased risk of 1 in $10^{6}$ ) assuming linear extrapolation to low-dose exposures typical of environmental pollution scenarios. Additionally, health advisories (HAs) are non-enforceable guidelines for emergency spills and treatment techniques (TTs) are applied where no adequate data exist to inform standards (Anonymous, 1988; Environmental Protection Agency, 1992; Environmental Protection Agency, 1999). The EPA does not have separate standards for total and individual pesticides, but under the US Food Quality Protection Act (EPA, 1997) the EPA must, when setting tolerance levels for pesticides, take into account available information concerning the cumulative effects of pesticides that have common mechanisms of toxicity.

Similarly, the WHO (WHO, 1993) bases its guideline values (GVs) for non-carcinogens on a percentage of a tolerable daily intake (TDI). Adjustments are made to take into account vulnerability of children (greater fluid intake per body mass) and for environmentally persistent chemicals. For carcinogens, the WHO's GVs are based on an "acceptable" increased risk of 1 in $10^{5}$ risk, also extrapolated linearly to low doses. Many countries adopt the WHO standards because it is too costly and complex to conduct their own risk assessment.

The EEC directives set maximum admissible concentrations (MACs) for pesticides in drinking water at the analytical detection limit for chlorinated pesticides, as a surrogate for a zero standard (Premazzi and Ziglio, 1995). The MAC is set at $0.1 \mu \mathrm{g} / \ell$ for any pesticide and $0.5 \mu \mathrm{g} / \ell$ for total pesticides.

By placing such low limits, the EEC has signalled that threshold limits are to be led by analytical capabilities and thereby as policy tools to reduce overall pesticide usage. There are a number of policy objectives underlying European standard-setting for pesticides including:

- The primacy of prevention, the "polluter pays" principle

- The optimal use of scientific information to inform standardsetting

- Application of the precautionary principle where data are insufficient

- The recognition of the transboundary nature of many pollution problems (Commission of the European Communities, 1996)

Some EU member states (Sijm et al., 2001; Babut et al., 2003) have begun developing different approaches to achieve the ambitious targets proposed under the European Union's water quality framework (EC Directives 1980 and 1998).

Along with standard-setting, the EEC uses other regulatory mechanisms to protect groundwater. For example, pesticides are registered only if they can be shown to be environmentally safe and will not be registered if they have "unacceptable" impacts on drinking water, or if no methods for analysis exist which can meet the levels of detection demanded by EEC standards (Premazzi and Zigio, 1995). EEC directs member countries to consider both health and environmental consequences under anticipated conditions of use and by taking into account scientific uncertainty and all routes of exposure.

\section{Some criticisms of regulatory approaches}

There are significant difficulties in establishing causation for chronic health outcomes from low-dose exposure, and of characterising a dose-response relationship, particularly for extremely low exposure levels typical of environmental exposures. While this uncer- 
TABLE2

Summary of international standards for pesticides in drinking water (mg/ $\ell$ )

\begin{tabular}{|c|c|c|c|c|c|c|c|c|c|c|}
\hline \multirow[t]{3}{*}{ Type of Standard: } & \multicolumn{8}{|c|}{ USEPA } & \multirow[t]{3}{*}{ Australian } & \multirow[t]{3}{*}{ WHO } \\
\hline & \multirow{2}{*}{$\begin{array}{c}\text { MCL } \\
\text { standard }\end{array}$} & \multicolumn{3}{|c|}{ Child advisories } & \multicolumn{3}{|c|}{ Adult advisories } & \multirow{2}{*}{$\begin{array}{l}\text { Advisory } \\
\text { at } 10-4 \\
\text { cancer } \\
\text { risk }\end{array}$} & & \\
\hline & & 1 day & 10 day & $\begin{array}{c}\text { Longer } \\
\text { term }\end{array}$ & $\begin{array}{l}\text { Longer } \\
\text { term }\end{array}$ & DWEL & Lifetime & & & \\
\hline \multicolumn{11}{|l|}{ Pesticide } \\
\hline Acifluorfen & & 2 & 2 & 0.1 & 0.4 & 0.4 & & 0.1 & & \\
\hline Alachlor & 0.002 & 0.1 & 0.1 & & & 0.4 & & 0.04 & 0.002 & 0.02 \\
\hline Aldicarb & 0.003 & 0.01 & 0.01 & & & 0.035 & 0.007 & & 0.001 & 0.01 \\
\hline Aldicarb sulfone & 0.003 & 0.01 & 0.01 & & & 0.035 & 0.007 & & & \\
\hline Aldicarb sulfoxide & 0 & 0.01 & 0.01 & & & 0.035 & 0.007 & & & \\
\hline Aldrin & & & 0.0003 & 0.0003 & 0.0003 & 0.001 & & 0.0002 & 0.0003 & 0.00003 \\
\hline Ametryn & & 9 & 9 & 0.9 & 3 & 0.3 & 0.06 & & 0.05 & \\
\hline Atrazine & 0.003 & 0.1 & 0.1 & 0.05 & 0.2 & 0.2 & 0.003 & & 0.02 & 0.002 \\
\hline Bentazon & & 0.3 & 0.3 & 0.3 & 1 & 1 & 0.2 & & 0.03 & 0.03 \\
\hline Bromacil & & 5 & 5 & 3 & 9 & 5 & 0.09 & & 0.3 & \\
\hline Butylate & & 2 & 2 & 1 & 4 & 2 & 0.35 & & & \\
\hline Carbaryl & & 1 & 1 & 1 & 1 & 4 & 0.7 & & 0.03 & \\
\hline Carbofuran & 0.04 & 0.05 & 0.05 & 0.05 & 0.2 & 0.2 & 0.04 & & 0.01 & 0.007 \\
\hline Carbon tetrachloride & 0.005 & 4 & 0.2 & 0.07 & 0.3 & 0.03 & & 0.03 & 0.003 & \\
\hline Chloramben & & 3 & 3 & 0.2 & 0.5 & 0.5 & 0.1 & & & \\
\hline Chlordane & 0002 & 0.06 & 0.06 & & & 0.002 & & 0.003 & 0.001 & 0.0002 \\
\hline Chlorotoluron & & & & & & & & & & 0.03 \\
\hline Chlorpyrifos & & 0.03 & 0.03 & 0.03 & 0.1 & 0.1 & 0.02 & & - & \\
\hline Cyanazine & & & & & & & & & & 0.0006 \\
\hline $2,4-\mathrm{D}$ & 0.07 & 1 & 0.3 & & & 0.4 & 0.07 & & 0.03 & 0.03 \\
\hline $2.4 \mathrm{DB}$ & & & & & & & & & & 0.09 \\
\hline 1.2-Dibromo-3-chloropropane & & & & & & & & & & 0.001 \\
\hline 1.2-Dibromoethane & & & & & & & & & & 0.0004 \\
\hline & & & & & & & & & & -0.0015 \\
\hline 1.2-Dichloropropane & & & & & & & & & & 0.004 \\
\hline 1.3-Dichloropropene & & & & & & & & & & 0.002 \\
\hline Dichlorprop & & & & & & & & & & 0.1 \\
\hline Dimethoate & & & & & & & & & & 0.006 \\
\hline Dieldrin & & 0.0005 & 0.0005 & 0.0005 & 0.002 & 0.002 & & 0.0002 & 0.0003 & 0.00003 \\
\hline Diphenamid & & 0.3 & 0.3 & 0.3 & 1 & 1 & 0.2 & & 0.3 & \\
\hline Diphenylamine & & 1 & 1 & 0.3 & 1 & 1 & 0.2 & & - & \\
\hline Diquat & 0.02 & & & & & 0.07 & 0.02 & & 0.005 & \\
\hline Disulfoton & & 0.1 & 0.1 & 0.003 & 0.009 & 0.001 & 0.0003 & & 0.003 & \\
\hline Endosulfan & & & & & & & & & 0.03 & \\
\hline Endothall & 0.1 & 0.8 & 0.8 & 0.2 & 0.2 & 0.7 & 0.1 & & 0.1 & \\
\hline Ethylene dibromide & 0.00005 & 0 & 0 & 0 & & & & 0.00004 & 0.001 & \\
\hline Endrin & & & & & & & & & & 0.0006 \\
\hline Fenamiphos & & 0.009 & 0.009 & 0.005 & 0.002 & 0.009 & 0.002 & & 0.0003 & \\
\hline Fonofos & & 0.02 & 0.02 & 0.02 & 0.07 & 0.07 & 0.01 & & - & \\
\hline Fenoprop & & & & & & & & & & 0.009 \\
\hline Glyphosate & & 20 & 20 & 1 & 1 & 4 & 0.7 & - & 1.0 & \\
\hline Heptachlor & 0.0004 & 0.01 & 0.01 & 0.005 & 0.005 & 0.02 & & 0.0008 & 0.0003 & 0.00003 \\
\hline Heptachlor epoxide & 0.0002 & 0.01 & 0.01 & 0.0001 & 0.0001 & 0.0004 & & 0.0004 & 0.0003 & 0.00003 \\
\hline Hexachlorobenzene & 0.001 & 0.05 & 0.05 & 0.05 & 0.2 & 0.03 & & 0.002 & & 0.001 \\
\hline Hexachlorocyclopentadiene & 0.05 & & & & & 0.2 & & & & \\
\hline Isoproturon & & & & & & & & & & 0.009 \\
\hline Lindane & 0.0002 & 1 & 1 & 0.03 & 0.1 & 0.01 & 0.0002 & & 0.00005 & 0.0003 \\
\hline Malathion & & 0.2 & 0.2 & 0.2 & 0.8 & 0.8 & 0.1 & & & \\
\hline MCPA & & & 0.1 & 0.1 & 0.4 & 0.02 & 0.004 & & & 0.002 \\
\hline
\end{tabular}


TABLE 2 (continued)

Summary of international standards for pesticides in drinking water $(\mathrm{mg} / \ell)$

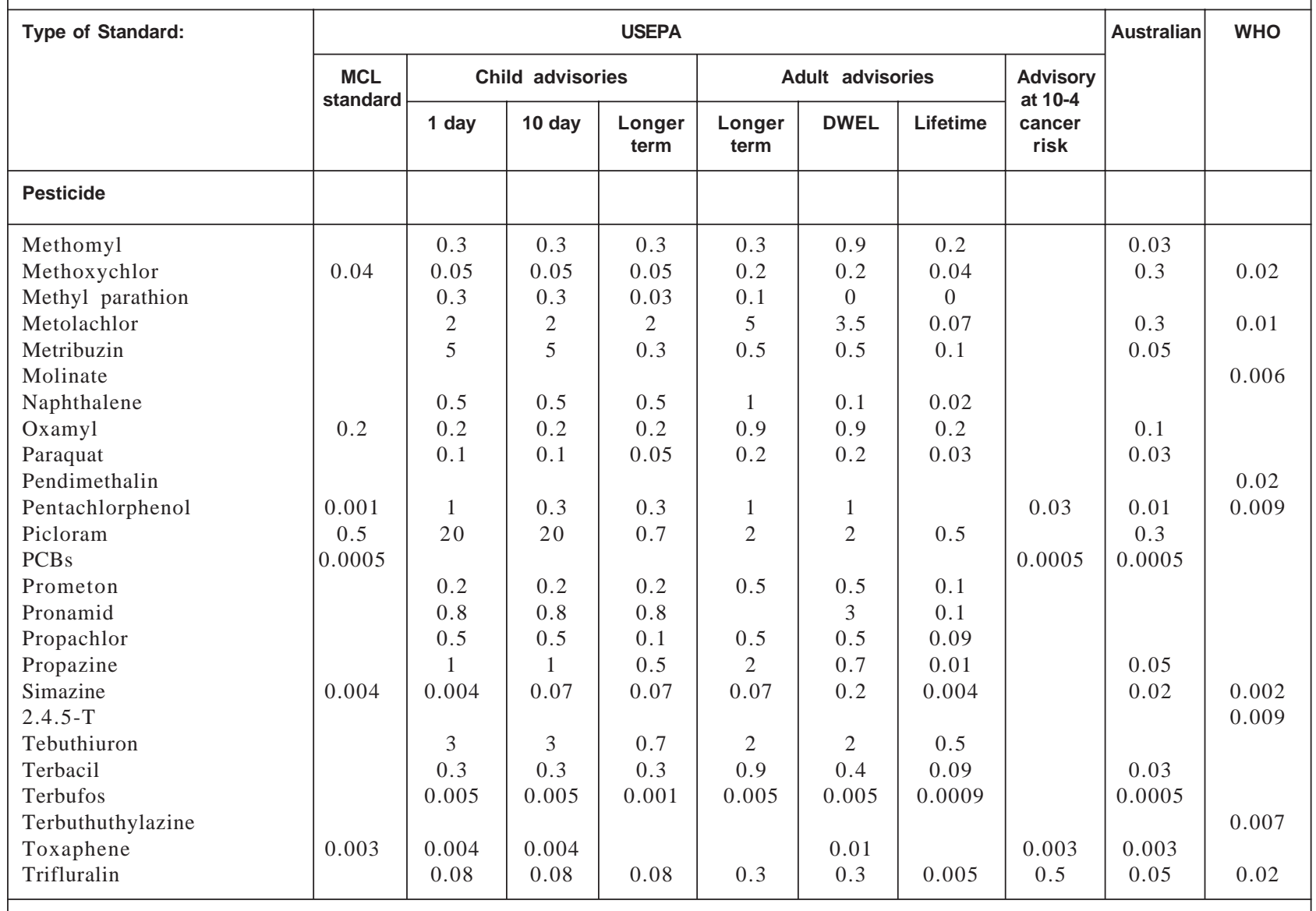

Sources: USEPA, 1986; WHO, 1993; National Health and Medical Research Council, and Agriculture and Resource Management Council of Australia and New Zealand, 1996; USEPA, 2002

MCL: Maximum contaminant level

DWEL: Drinking water equivalent level

tainty in epidemiological research is recognised in the scientific community, it is not easily considered by policy-makers (Macrory, 1998) who rely on a burden-of-proof approach that facilitates administrative decision-making.

Health-based limits for pesticides in water (such as those developed by the EPA and WHO) have been severely criticised (Premazzi and Ziglio, 1995; Anonymous, 1996) because of the reliance on empirical evidence, which is lacking for the majority of pesticides, meaning that most pesticides remain without standards. For example, the WHO has drinking water standards for only a small proportion of the thousands of pesticide active ingredients manufactured and many that do have standards are pesticides that are no longer in general use (Whyatt, 1990).

Moreover, current toxicological models do not adequately address the problem of mixtures which is the most common scenario for exposure, particularly in developing countries. The WHO method of providing for mixtures is by incorporating safety factors into standards, by considering individual pesticide as additive and by stating that special considerations should be made where mixtures could be a problem. Although the WHO, in theory, accommodates differential risks for particularly vulnerable groups, only one (DDT) of the 36 pesticides for which GVs have been established in two sets of guidelines since 1993(WHO, 1993; 2004), provides standards for infant intake. The linear extrapolation to low-dose effects used to estimate acceptable risk from pesticides known as carcinogens may be an incorrect assumption (Perera and Boffetta, 1988). Lastly, epidemiological studies investigating the health effects due to low exposure levels generally require large study samples, with attendant high costs, and imply the exposure of large numbers of people to the pesticides under study. It is thus little surprise that so little data exist to inform standards for pesticides.

On the other hand, the policy-based approach of the EEC imposes standards set by analytical capabilities that may be difficult or impossible to enforce in developing countries where technological capacity and human resources are limited and public awareness of pesticide exposure hazards are low. Moreover, standards that are not health-based may themselves over- or under-estimate health risks.

\section{National and international environmental policy developments}

South Africa's legislation on pesticides is extremely complex and fragmented, being spread across 14 Acts and 7 different government departments (Rother and London, 1998). However, a number of key 
changes have taken place in the legislative framework dealing with the environment.

Firstly, the overall framework for national environmental management is set by the National Environmental Management Act (Department of Environmental Affairs and Tourism, 1999), in terms of which the Department of Environmental Affairs and Tourism (DEAT) is endorsed as the leadagency in co-ordinating environmental policy. Amongst the policy principles contained in the Act are an emphasis on prevention, the need to minimise negative environmental impacts if pollution cannot be avoided, environmental justice and a risk-averse and cautious approach which takes into account the limits of current knowledge about environmental decision making.

In addition, the Department of Water Affairs and Forestry (DWAF) has introduced a range of legislation changing the nature of water management and related environmental practices in South Africa (DWAF, 1996 a \& b; DWAF, 1997; DWAF, 1998 a \& b). Chief in this process is the introduction of water management by catchment, a pricing system to support equity and sustainability of water resources, and regulation according to water quality objectives rather than a sole reliance on uniform effluent emission standards (Lazarus et al.,1997). The Act also emphasises public participation and provides for greater community involvement in water management structures. In addition, DEAT is currently finalising a National Chemicals Profile as a basis for reevaluating South Africa's capacity for safe management of chemicals (DEAT, 2004). Within this process of improving chemicals management, it may be possible to address the problem of water pollution by pesticides.

A number of international policy developments focus on pesticides. For example, the United Nations Environment Programme(UNEP) protocol to eradicate persistent organic pollutants (POPS) will see the phasing out of a number of pesticides deemed to pose a risk of irreversible harm on a global scale (UNEP, 1999). National governments are encouraged to undertake monitoring for these pesticides in water to assist in their eradication.

\section{South African options}

Recent studies (London et al., 2000; Meintjies et al., 2000; Schultz, 2001; Dalvie et al., 2003, Sereda and Meinhardt, 2003) have confirmed widespread contamination by pesticides of surface- and groundwater at low concentrations in South Africa, confirming the existence of a problem requiring an appropriate policy response. How can concerns for pesticide safety be integrated with environmental regulation and risk assessment in South Africa drawing on the different international models for regulating pesticides in drinking water? As a minimum, consideration should be given to developing and adopting health-based standards for pesticides in drinking water on which to base protective measures. The WHO and EPA standards could easily be used as a starting point as has been done for occupational health and safety
TABLE3

Water standards to protect aquatic ecosystems (mg/l)

\begin{tabular}{|c|c|c|c|c|c|}
\hline Substance & $\begin{array}{l}\text { South } \\
\text { Africa }\end{array}$ & $\begin{array}{l}\text { United } \\
\text { Kingdom }\end{array}$ & USEPA & Australia & Canada \\
\hline Aldrin & 0.01 & 0.01 & & 0.01 & 0.004 \\
\hline Arsenic & & & & & 0.005 \\
\hline Atrazine & 0.01 & & & & 0.0018 \\
\hline Azinphos-methyl & & & & 0.01 & \\
\hline Bromacil & & & & & 0.005 \\
\hline Bromoxynil & & & & & 0.005 \\
\hline Captan & & & & & 0.0013 \\
\hline Carbaryl & & & & & 0.0002 \\
\hline Carbofuran & & & & & 0.0018 \\
\hline Chlordane & 0.025 & & & 0.004 & 6.0 \\
\hline Chlorothalonil & & & & & 0.00018 \\
\hline Chlorpyrifos & & & & 0.001 & 0.000002 \\
\hline Cyanazine & & & & & 0.002 \\
\hline DDT & 0.0015 & 0.025 & & 0.0005 & 0.001 \\
\hline Deltamethrin & & & & & 0.0000004 \\
\hline Dicamba & & & & & 0.01 \\
\hline Dichlorophenols & & & & & 0.0002 \\
\hline Diclofop-methyl & & & & & 0.0061 \\
\hline Dieldrin & 0.005 & 0.01 & & 0.002 & \\
\hline Dimethoate & & & & & 0.0062 \\
\hline Dinoseb & & & & & 0.00005 \\
\hline Endosulfan & 0.00001 & & & 0.001 & 0.00002 \\
\hline Endrin & 0.002 & & 0.05 & 0.003 & 0.0023 \\
\hline Heptochlor & 0.005 & & & 0.0003 & \\
\hline Lindane & 0.015 & & & 0.003 & 0.00001 \\
\hline Linuron & & & & & 0.007 \\
\hline Malathion & 0.1 & & & 0.07 & \\
\hline MCPA & & & & & 0.0026 \\
\hline Methoxychlor & 0.02 & & & 0.04 & \\
\hline Metolachlor & & & & & 0.0078 \\
\hline Metribuzin & & & & & 0.001 \\
\hline Mirex & 0.001 & & & 0.001 & \\
\hline Monochlorophenols & & & & & 0.007 \\
\hline Parathion & 0.008 & & & 0.004 & \\
\hline Pentachlorophenol & & & & & 0.0005 \\
\hline Simazine & & & & & 0.01 \\
\hline Tebuthiuron & & & & & 0.0016 \\
\hline Tertrachlorophenols & & & & & 0.001 \\
\hline Toxaphene & & & & 0.002 & \\
\hline Trichlorophenols & & & & & 0.018 \\
\hline Trifluralin & & & & & 0.000020 \\
\hline 2,4 Dichlorophenol & 4.0 & & & & 4.0 \\
\hline
\end{tabular}

Sources: Dallas and Day, 1993; DWAF, 1996 b; USEPA, 2002; Canadian Council of Ministers of the Environment, 2004; Drinking Water Inspectorate (UK), 2003; WHO, 2004. standards for chemical exposures at the workplace (Ehrlich, 1985). These international health-based standards would not be overly burdensome to apply in South Africa. At the very least they would provide health protection presently not available to South Africans, and would be in line with the Constitution seeking to provide citizens with a right to an environment that is not harmful to health.

However, it is well recognised that the health-based limits are severely constrained in their ability to provide standards with adequate human and environmental protection in relation to the 
myriad existing and new pesticides entering the environment. For example, in the absence of adequate toxicological data to determine the presence of potential health effects, as is the case for the majority of pesticides, it has been argued that standards should be set at the level of detection (Whyatt, 1990). Consideration should therefore be given to exploring application of more stringent standards, such as those predicated on the precautionary principle and similar to those adopted by the EU. Such an approach should ideally be negotiated within the national chemicals profile initiative under DEAT as part of a coherent policy framework (DEAT, 2004). Notably, given the fact that pesticides are not appreciably removed during conventional water treatment processes unless activated carbon filtering (Barnes and Kalita, 2001) or one of a number of other catalytic processes such as ozonation, nano-filtration and ultraviolet processes is used, the costs of remediating pesticide contamination of water sources used for drinking are high enough to warrant concentration control at source.

Lastly, without the capacity to monitor the sale, application and environmental fate of pesticides it will be impossible to establish the basis for policy and regulation. Under the Rotterdam Convention, The Prior Informed Consent Procedure for International Trade of Hazardous Chemicals and Pesticides requires exporters to provide adequate information on human health or environmental risks, taking into account relevant international standards prior to export (United Nations Environment Programme, 2004). As most pesticides in South Africa are imported, this convention which came into force on 24 February 2004 provides a means of monitoring the sale of these chemicals. Environmental policy-makers will need to look to strengthening capacity at local levels to ensure that communities and local government are able to manage environmental threats to human health. Such measures would ensure consistency with recent developments in environmental management in South Africa that give primacy to a number of key environmental policy principles. A public health perspective should ensure that growing international concerns for long-term adverse health and environmental impacts arising from the presence of pesticides in water are adequately addressed in regulatory controls in South Africa.

\section{Acknowledgements}

This research was conducted as part of a 3-year project supported by the SA Water Research Commission (WRC), and by a grant from the South African Medical Research Council.

\section{References}

ANONYMOUS (1988) Introduction to health advisories for 16 pesticides. Rev. Env. Contam. Toxicol. 104 1-8.

ANONYMOUS (1996) New WHO Guidelines for pesticides in water. Pesticide News 3330.

ANONYMOUS (2003) US EPA considers testing pesticides on people. Global Pesticide Campaigner 13 (2) 29. Accessed at http:// www.panna.org/resources/gpc/gpc 200308.13.2.pdf on 14 January 2004.

BABUT M, CORINNE B, MARC B, PATRICK F, JEANNE G and GENEVIEVE G (2003) Developing environmental quality standards for various pesticides and priority pollutants for French freshwaters. J Environ. Manage. 69 139-47.

BARNES PL and KALITA PK (2001) Watershed monitoring to address contamination source issues and remediation of the contaminant impairments. Water Sci. Technol. 44 51-6.

CANADIAN COUNCIL OF MINISTERS OF THE ENVIRONMENT (2004) Canadian Environmental Quality Guidelines. http:// www.ccme.ca/assets/pdf/e1 062.pdf

COLOSIO C, TIRAMANI M and MARONI M (2003) Neurobehavioral effects of pesticides: State of the art. Neurotoxicol. 24 577-91.
COMMISSION OF THE EUROPEAN COMMUNITIES (1996) European Community Water Policy. Brussels.

DALLAS HF and DAY JA (1993) The Effect of Water Quality Variables on Riverine Ecosystems: A Review. Report prepared for the Water Research Commission. August 1993. Freshwater Research Unit, University of Cape Town, Rondebosch, 7700.

DALVIE MA, CAIRNCROSS E, SOLOMON and LONDON L (2003) Contamination of rural surface and ground water by endosulfan in farming areas of the Western Cape, South Africa. Environ. Health: A Global Access Sci. Source 2 (1). http://www.ehjournal.net/ content/2/1/1. [electronic journal]

DALVIE MA, WHITE N, RAINE R, MYERS JE, LONDON L. THOMPSON ML and CHRISTIANI D (1999) Long-term respiratory health effects of the herbicide paraquat among Western Cape farm workers. Occup. Environ. Med. 56 391-396.

DALVIE MA, CAIRNCROSS E, ADAMS H, SOLOMONS A and LONDON L (2002) Cost-Effective Methods for Monitoring Pesticide Pollution in Water Systems: Technologies and Procedures For Field Use in Rural Areas. Final report to the Water Research Commission. Project K5/1120. November .

DEPARTMENT OF ENVIRONMENTAL AFFAIRS AND TOURISM (1999) National Environmental Management Act. Act 107 of 1998. Government Gazette 1 July 1998, Vol. 397,(19031). Government Printers, Pretoria.

DEPARTMENT OF ENVIRONMENTAL AFFAIRS AND TOURISM (2004) National Chemicals Management Profile: Background. Accessed on 13 January at URL: 2004 http:// www.environment.gov.za/.

DEPARTMENT OF WATER AFFAIRS AND FORESTRY (1996a) South African Water Guidelines. Vol. 1: Domestic Water Use $\left(1^{\text {st }}\right.$ edn.). DWAF: Pretoria.

DEPARTMENT OF WATER AFFAIRS AND FORESTRY (1996b) South African Water Guidelines. Vol. 7: Aquatic Ecosystems (1 $1^{\text {st }}$ edn.). DWAF: Pretoria.

DEPARTMENT OF WATER AFFAIRS AND FORESTRY (1997) White Paper on a National Water Policy for South Africa. Pretoria.

DEPARTMENT OF WATER AFFAIRS AND FORESTRY (1998a) National Water Act. Act 36/1998. Pretoria.

DEPARTMENT OF WATER AFFAIRS AND FORESTRY (1998b) National Water Act. Act 107/1998. Pretoria.

DINHAM B (1993) The Pesticide Hazard. A Global Health and Environmental Audit. Pesticide Trust. Zed Books, London.

DRINKING WATER INSPECTORATE (UK) (2003) Guardians of Drinking Water Quality. Interim Guidance on the Water Supply (Water Quality) Regulations 2000 (England) and the Water Supply (Water Quality) Regulations 2001 (Wales). Drinking Water Inspectorate (UK).

EEC (1980) EC Directive Relating to the Quality of Water Intended for Human Consumption, 80/778/EEC. Luxembourg: Office for Official Publications of the European Communities, 1980.

EEC (1998) EC Directive on the Quality of Water Intended for Human Consumption, 98/83/EC. Luxembourg: Office for Official Publications of the European Communities, 1998.

EHRLICH R (1995) The hazardous chemical substances regulations: Occupational health comes of age in South Africa. Occup. Health South. Afr. 1 (6) 12-15.

GRAY LE and OSTBY J (1998) Effects of pesticides and toxic substances on behavioural and morphological reproductive development: endocrine versus nonendocrine mechanisms. Toxicol. Ind. Health 14 159-184

KAMENETSKY H (2003) Human data debate. US environment agency considers ethics and utility of toxics tests on human volunteers. The Scientist. Accessed on 14 January 2003. http:// www.biomedcentral.com/news/20030110/04/.

KIRKHORN SR and SCHENKER MB (2002) Current health effects of agricultural work: Respiratory disease, cancer, reproductive effects, musculoskeletal injuries, and pesticide-related illnesses. J. Agric Saf. Health 8 199-214.

LAZARUS P, CURRIE I and SHORT R (1997) The legislative framework. Environmental law, investment and industrial practice. In: Bethlehem L and Goldblatt M (eds.) The Bottom Line. 
Industry and the Environment in South Africa. Chapter 1. University of Cape Town Press, Rondebosch, South Africa. 9-29.

LONDON L, DALVIE MA, CAIRNCROSS E and SOLOMON A (2000) The Quality of Surface and Groundwater in the Rural Western Cape with Regard to Pesticides. WRC Report No 795/1/00. WRC, Pretoria.

LONDON L and ROTHER A (1998) People, pesticide and the environment: Who bears the brunt of backward policy in South Africa? In: Proc. Conf. on Environmental Justice and the Legal Process. Environmental Law Unit, University of Cape Town, Cape Town, South Africa and Environmental Law Centre, Macquarie University, Sydney, Australia. April.

MACRORY R (1998) Environmental Standards, Legitimacy and Social Justice. In: Proc. Conf. on Environmental Justice and the Legal Process. Environmental Law Unit, University of Cape Town, and Environmental Law Centre, Macquarie University, Sydney. April. 12-19.

MARONI M and FAIT A (1993) Health effects in man from long-term exposure to pesticides. A review of the 1975-1991 literature. Toxicol. 78 1-174.

McKAY J and MOELLER A (2001) Is risk associated with drinking water in Australia of significant concern to justify mandatory regulation? Environ. Manage. 28 (4) 469-81.

MEINTJIES E, VAN DER MERWE L and DU PREEZ JL (2000) Qualitative and Quantitative Evaluation of Estrogen-Mimicking Substances in the Water Environment. WRC Report No 742/1/00. WRC, Pretoria.

NATIONAL HEALTH AND MEDICAL RESEARCH COUNCIL, AND AGRICULTURE AND RESOURCE MANAGEMENT COUNCIL OF AUSTRALIA AND NEW ZEALAND (1996) Australian Drinking Water Guidelines. National Water Quality Management Strategy. Canberra.

PERERA F and BOFFETTA P (1988) Perspectives on comparing risks of environmental carcinogens. J. Natl. Cancer Inst. 80 (16) 12821293.

PORTER W, JAEGER JW and CARLSON IH (1999) Endocrine, immune and behavioural effects of aldicarb (carbamate), atrazine (triazine) and nitrate (fertiliser) mixtures at groundwater concentrations. Toxicol. Ind. Health 15 133-150.

PREMAZZI G and ZIGLIO G (1995) Regulations and Management. In: Vighi $\mathrm{M}$ and Funari E (eds.) Pesticide Risk in Groundwater. Chapter 10. CRC Lewis Publishers, Boca Raton. 203-240.

ROTHER HA and LONDON L (1998) Pesticide Health and Safety Policy Mechanisms in South Africa: The State of the Debate. Occupational and Environmental Health Research Unit Working Paper 1. April 1998. Department of Community Health, University of Cape Town.

SCHETTLER T, SOLOMON G, BURNS P and VALENTI M (1996) Generations at Risk. How Environmental Toxins may affect Reproductive Health in Massachusetts. Greater Boston Physicians for Social Responsibility, Massachusetts Public Interest Research Group (MASSPIRG) Education Fund, Cambridge.

SCHULZ R (2001) Comparison of spraydrift- and runoff-related input of azinphos-methyl and endosulfan from fruit orchards into the Lourens River, South Africa. Chemosphere 45 543-551.

SEREDA BL and MEINHARDT HR (2003) Insecticide Contamination of the Water Environment in Malaria Endemic Areas of KwaZulu-Natal (SA): The Risk of Insecticide Resistance Development in Malaria Vectors. WRC Report No 1119/1/03. WRC, Pretoria.

SIJM D, DE BRUIJN J, CROMMENTUIJN T and VAN LEEUWEN K (2001) Environmental quality standards: Endpoints or triggers for a tiered ecological effect assessment approach? Environ. Toxicol. Chem. 20 (11) 2644-2648.

UNITED NATIONS ENVIRONMENTAL PROGRAMME (UNEP) (1999) International Activities related to Chemicals. Excerpts from a report on "Enhanced Coherence and Efficiency among International Activities Related to Chemicals" presented to the $20^{\text {th }}$ session of the Governing Council of UNEP in 1999 by the Executive Director. UNEP Chemicals, Geneva.

UNEP (2004) Rotterdam Convention. Web: http://www.pic.int/en/ ViewPage.asp?id=104.

UNITED STATES ENVIRONMENTAL PROTECTION AGENCY (EPA) (1992) Guidelines For Drinking Water Quality. US Environmental - Washington, DC. 202-260-7572.

US EPA (1997) Guidance for Establishing a Common Mechanism of Toxicity for Use in Combined Risk Asssessment. http:// www.epa.gov/oppfead1/fqpa/SAP/criter 4.htm

UNITED STATES ENVIRONMENTAL PROTECTION AGENCY (1999) Science Policy 5: Estimating the drinking water component of a dietary exposure assessment (12/22/98 Draft). http:/ www.epa.gov/docs/fedregstr/EPA-PEST/1999/January/Day-04/ 6028.htm.

UNITED STATES ENVIRONMENTAL PROTECTION AGENCY (1986) Quality criteria for water - 1986. USEPA. Washington, DC.

UNITED STATES ENVIRONMENTAL PROTECTION AGENCY (2002) 2002 Edn. of the Drinking Water Standards and Health Advisories. EPA 822-R-02-038. EPA (Office of water): Washington, DC.

WHO (1993) Guidelines for Water Quality. Volume II. Health Criteria and Other Supporting Information. World Health Organisation, Geneva

WHO (2004) Guidelines for Drinking-Water Quality ( $3^{\text {rd }}$ edn.) Chapter 8. Chemical Aspects.

http://www.who.int/docstore/water_sanitation_health/GDWQ/ Updating/draftguidel/draftchap81.htm

WHYATT RM (1990) Setting human-health-based groundwater protection standards when toxicological data are inadequate. Am. J. Ind. Med. 18 505-10. 
